\title{
TCL6 wt Allele
}

National Cancer Institute

\section{Source}

National Cancer Institute. TCL6 wt Allele. NCI Thesaurus. Code C97832.

Human TCL6 wild-type allele is located in the vicinity of $14 q 32.1$ and is approximately 42

$\mathrm{kb}$ in length. This allele, which encodes T-cell leukemia/lymphoma 6 long non-protein coding RNA, is involved in T-cell leukemias. 